\title{
INFLUENCE OF FLAVORS AND STABILIZERS USED ON THE PREFERENCES AND PROPERTIES OF AERATED TVAROG CURD CHEESE
}

\author{
Beata Treszczynska, Aneta Siwek, Jaroslaw Kowalik ${ }^{\bowtie}$, Adriana Lobacz, \\ Justyna Zulewska \\ Department of Dairy Science and Quality Management, Faculty of Food Sciences, University of Warmia and Mazury \\ Oczapowskiego 7, 10-719 Olsztyn, Poland
}

\begin{abstract}
Background. The Polish market for tvarog (curd cheese)-based products is growing continuously. The assortment of these goods include products with different textures, different additives and different flavours. In developing a successful food product one should ensure consumers are sufficiently involved during the development stages. Consumer-led food product development should be a standard procedure. The study aimed to develop a new variants of aerated tvarog spreads.

Material and methods. The research was divided into the following steps: evaluation of consumer preferences (questionnaire); production of aerated tvarog cheeses (different flavor variants); physico-chemical evaluation of new products (composition, TPA test); evaluation of new products by consumers (questionnaire with a 5-point scale); sensory evaluation of new products by an expert panel (2 types of questionnaire).

Results. Sweet tvarog spreads were characterized by a higher degree of aeration than cheeses with a savory flavor. The savory variants had a semi-liquid consistency after aeration. This could result from the addition of salt $(6 \%)$ to flavor preparation. The products stabilized by gelatine showed a higher degree of aeration than the ones with starch. The savory cheeses showed lower hardness than sweet cheeses $(P<0.05)$. Both consumers and experts gave higher marks to the sweet variants of manufactured tvarog cheeses.

Conclusion. The addition of salt to savory flavor preparation probably affected the texture of these products, which was semi-liquid. Texture plays a very important role in the development of new products and affects consumers' preferences for the product.
\end{abstract}

Keywords: aerated tvarog spread, consumer preferences, tvarog

\section{INTRODUCTION}

To operate on the market companies must produce and sell their products. A company must be innovative to in order be profitable and grow its own business. A new product satisfying the needs of the consumer contributes to the development and increase of the economic results of the manufacturer (Moskowitz et al., 2006).

Innovation is the process of transforming existing possibilities into new ideas that have practical use. Innovation refers to completely new solutions, as well

Funding Source Declaration: University grant - statutory research.

『j.kowalik@uwm.edu.pl 
as modifications made to an existing product, service or process. When designing a new product, a company can borrow already existing solutions from other sectors, countries or areas of life. When innovating, it is important to think in a creative and unconventional way, in order to open unknown possibilities. It is the consumer who decides whether a new product will be accepted, and the consumer also plays a significant role in every stage of the product design, during development and testing, as well as during production and sales (Earle et al., 2001; Moskowitz et al., 2006).

There is no clear definition of a new food product. This term can be understood in various ways, depending on the context (Bobel, 2008) and the perspective (company versus consumer). Even small changes in the product can cause a product to be recognized as new. Most often, it is assumed that the new product is a product that has not been previously proposed, sold or manufactured by the company or any new form of the product, which is regarded by consumers as a novelty (MacFie, 2007; Sojkin and Olejniczak, 2009).

Fresh cheeses are unripened cheeses which are manufactured by the coagulation of milk, cream or whey using acid, a combination of acid and rennet or a combination of acid and heat. Fresh cheeses can be consumed immediately after production. In most countries and cultures, there is some traditional form of fresh cheese (Schultz-Collins and Senge, 2004). With increased globalisation and tourism, the various regional types of fresh cheese have begun to spread outside their regions of origin. Cream cheese, cottage cheese, quark or tvarog, fromage frais and Ricotta are among the better-known types. Tvarog is a product very popular in Eastern European countries. In Germany it is known under the name quark. Poland and Russia are among the biggest producers of tvarog and tvarog-type cheeses represent up to two-thirds of total cheese consumption in these countries (Mann, 2000; Rouyer, 1997). The consumption of fresh cheeses is also very high in USA, some European countries (Germany, France, Italy), and also in the Middle East (e.g. Israel) (Rouyer, 1997).

Tvarog is usually produced from pasteurized milk by proper treatment of acid curd produced by lactic acid bacteria. In Poland, tvarog is classified in terms of fat content as full-fat, fat and skimmed with 8,4 and $<0.5 \%$ fat, respectively. The typical composition of tvarog produced using acid coagulation is $72-78 \%$ water and $12-20 \%$ protein. Water content depends on the fat content. The $\mathrm{pH}$ value is between 4.4-4.6 and titratable acidity is in the range $80-100^{\circ} \mathrm{SH}$ (Rymaszewski and Smietana, 1997). Tvarog is a product category attractive to the consumer, due to the large product variety, high protein content and relatively low price. The main products on the Polish tvarog cheese market are tvarog, tvarog varieties (i.e. aerated, sliced, spreads) and homogenized tvarog with additives for baking. In Poland, tvarog is very often consumed as an ingredient of different dishes, i.e. cheesecakes, sauces or desserts (Guinee et al., 1993; Kroger, 1980; Siggelkow, 1984). The common way of consuming tvarog is to mix it with cream and add different ingredients, i.e. spices, jam, fruit paste. Tvarog is a classic mainstay of tradition, and also a great segment for innovative products. Over 100 Polish dairy companies offer products in this category. According to the 2017 data from the Central Statistical Office (GUS), 796,000 tons of cheese were produced in Poland, among which 451,000 tons was tvarog (Rynek mleka..., 2017). At present, there is an increase in the production of dairy products, mainly tvarog cheeses, which were subjected to aeration with nitric oxide. Such products are very popular among consumers, as the aeration intensifies taste fullness. Recently, there is also growing interest in the better use of milk components in the final product. This can be achieved by the application of ultrafiltration or the addition of transglutaminase enzyme. Both approaches allow the use of whey proteins derived from the raw material in the final product. Retention of whey proteins results in an increase in nutritional value and greater productivity (Siemianowski et al., 2013). Today, manufacturers also offer flavored versions of classic tvarog cheeses, with the commonly used additives, such as chives, radishes and herbs. Some dairies offer sweet tvarogs, such as chocolate or baked apples, which are especially popular in a homogenized form, as cheese cake tvarog.

The aim of the study was to investigate consumers' preferences regarding tvarog cheeses, to develop a recipe and to produce new products in this category, and to evaluate consumer acceptance of them. 


\section{MATERIAL AND METHODS}

The research was divided into the following steps:

- assessment of tvarog and quark cheeses available on the market

- evaluation of consumer preferences

- production of aerated tvarog cheeses

- physico-chemical evaluation of new products

- evaluation of new products by the consumers

- sensory evaluation of new products by expert panel.

To determine whether there were significant differences among the samples all data were analyzed by ANOVA using Statistica (version 13.1, 1984-2016, StatSoft, Inc., Tulsa, OK).

\section{Evaluation of consumer preferences}

Consumer preferences regarding tvarog products were determined using an online survey (14 questions). Fiftytwo people participated in the study. The questions concerned the frequency and occasions of consumption, the type and form of products consumed, choice patterns and suggestions for new flavors.

\section{Production of aerated tvarog cheeses}

Based on the results of the consumer preference survey, four flavor variants were chosen for product development: (1) baked apple with cinnamon, (2) elderberry with wild rose and blueberry, (3) spinach with herbs, (4) mushrooms with onion.

The flavor preparations used to manufacture new variants of the product were delivered by a specialist company on request. Each flavor variant was prepared in two versions. Two different stabilizers were applied to manufacture the flavor preparation: modified corn starch or beef gelatin. No additional stabilizers were used to stabilize the degree of aeration.

The raw material for the production of a semifat tvarog was purchased directly from the Lubawa branch of the Polish dairy company SM Mlekovita and was kept in a refrigerator (at a temperature of $4^{\circ} \mathrm{C}$ ) until new products were manufactured. Tvarog cheese was milled in a colloid mill (Młynkol, Józefów, Poland) and was divided into 8 portions. $3 \%$ of milk with $3.2 \%$ milk fat and $12 \%$ flavor preparation was added to each portion, followed by mixing, and then the prepared mixtures were aerated with nitrogen using a MiniMondo device (Haas-Mondomix BV, Almere, The Netherlands) at settings suggested by the manufacturer (inlet pressure 6 bars, pressure in mixing chamber 4 bars). Next, each flavor variant was packed in plastic containers (approximately $150 \mathrm{~g}$ in each container) and immediately cooled.

The control sample was a natural tvarog cheese, which consisted of milled tvarog aerated with nitrogen.

\section{Physico-chemical evaluation of new products}

The protein, fat and moisture content was determined with FoodScan (Foss, Hillerod, Denmark) using nearinfrared spectroscopy. Each sample was examined in triplicate.

The degree of aeration $(\% \mathrm{~N})$ was expressed as the percentage increase in the volume of the aerated cheese in relation to the volume of the cheese mix (before aeration), and calculated using the following formula:

$$
\% \mathrm{NT}=\frac{T-T_{1}}{T_{1}} \cdot 100
$$

where:

$T$ - the mass of the quark cheese mix, $\mathrm{g}$,

$T_{1}$ - the mass of the same volume of aerated quark cheese, $g$.

Texture profile analysis (TPA) was carried out on a TA.XT Plus Stable Microsystems LTD (Surrey, UK) texture analyzer using Texture Exponent 32 computer software. The test consisted of double insertion of the flat cylindrical (diameter of $30 \mathrm{~mm}$ ) probe at a speed of $2 \mathrm{~mm} / \mathrm{s}$ to a depth of $10 \mathrm{~mm}$. The sample $(150 \mathrm{~g})$ was placed in a plastic container $(10 \mathrm{~cm}$ diameter, $5 \mathrm{~cm}$ height), the same that was used for packing the product after production. Each sample was checked for the following parameters: hardness, fracturability, adhesiveness, springiness, cohesiveness, gumminess, chewiness, resilience.

\section{Evaluation of new products by consumers}

Four new products containing modified starch as stabilizer were evaluated by consumers. The overall appearance, color, texture, aroma, perception of the additives and general sensation of the product were evaluated using a 5-point scale. The questionnaire included a description of the features which the product should have to obtain a particular mark. Consumers 
were also asked to identify their preferred product in each category and to identify the additives used. The evaluation was carried out by 35 people with unproven sensory sensitivity.

\section{Sensory evaluation of new products by a panel of experts}

Eight new flavoured products and a natural flavor sample (control sample) were evaluated by the expert panel. The appearance, texture, aroma, and flavor were evaluated on a 7-point scale. Moreover, the overall sensory sensation was rated using a 5-point scale. Sensory evaluation was carried out by 10 qualified individuals experienced in the sensory evaluation of dairy products.

\section{RESULTS AND DISCUSSION}

\section{Evaluation of consumer preferences}

All participants in the survey declared that they consume tvarog and/or tvarog cheeses. The respondents consume such products quite often: $35 \%$ a few times a week and $29 \%$ once a week. Most often traditional natural tvarog is consumed (as declared by 37 people), although both aerated and untreated tvarog cheeses (different varieties) are also getting a lot of attention. Eleven people declared that they consume all kinds of tvarog products. According to the respondents, the preferred flavor was natural (as declared by 58\% of respondents). Interestingly, $16 \%$ of respondents

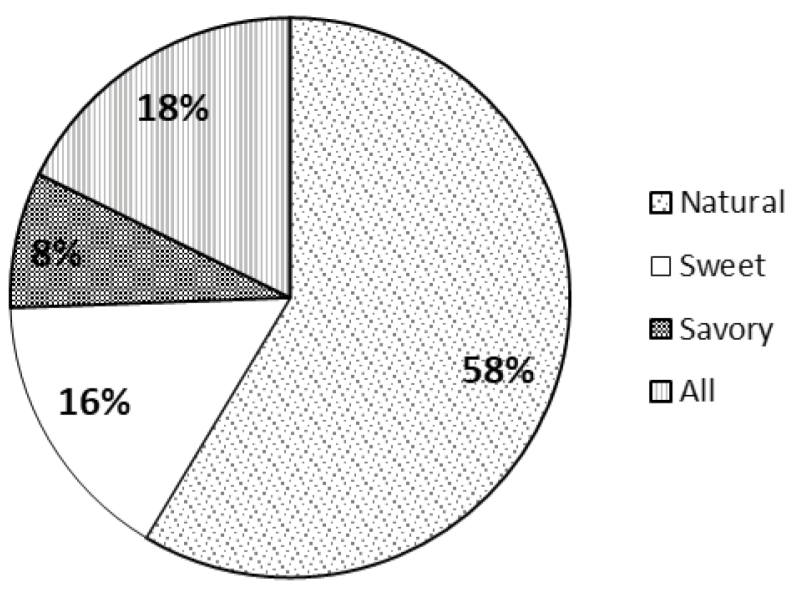

Fig. 1. The flavors chosen by respondents preferred sweet flavors, while only $8 \%$ preferred spicy; $18 \%$ chose the answer "all suit me to the same extent" (Fig. 1).

Most respondents use different additives when preparing meals with tvarog and serve them in many ways, both sweet and spicy. Most people consume products from the tvarog category with sandwiches (40 persons), for pancakes (31 people) or simply as tvarog itself (27 people) (Fig. 2).

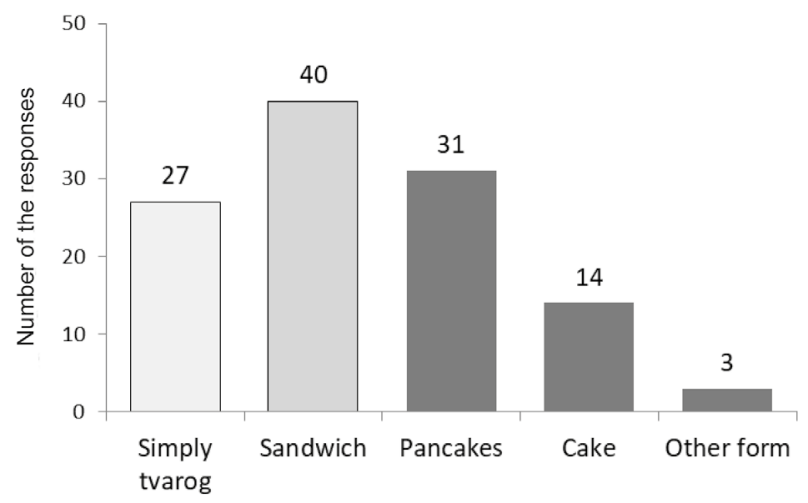

Fig. 2. The ways of consuming tvarog

Composition and nutritional value were the most important factors when choosing tvarog and tvarog cheeses (Fig. 3). Additionaly, consumers pay attention to the additives used, price and packaging. For $77 \%$ of the respondents the assortment of tvarog and tvarog varieties available in the stores was sufficient, although $70 \%$ of respondents were willing to choose a new product, if there was one.

The survey suggested 13 new flavors that could be used in the production of tvarog cheeses. New flavours were chosen after a thorough analysis of tvarog and tvarog varieties available on the market. Natural flavor together with herbs and garlic variants were available in all visited stores (9 supermarkets). Common additives were also cucumber, chives, horseradish and salmon (available in 8 stores). Less popular additives were: pepper, tomato, roasted onion, radish or porcini mushrooms (each available in 7 stores) and pepper, cucumber with dill, ham, apple-pear or berry-raspberry (6 stores). A review of the flavours available on the market showed that atypical flavors were also offered by different brands, such as mustard and honey, 


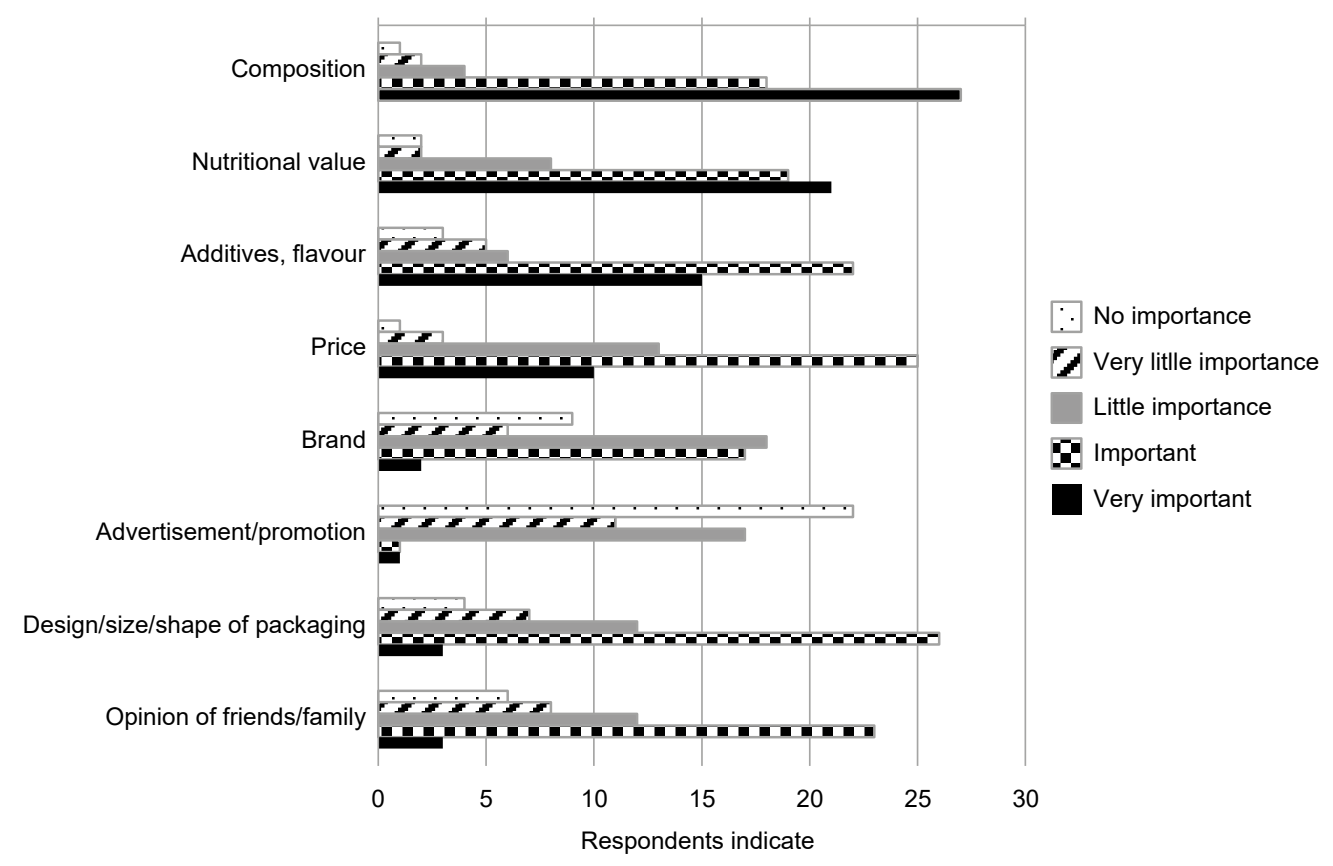

Fig. 3. The factors influencing the choice of tvarog and tvarog varieties

papaya-curry, pesto with arugula, porcini mushrooms or Mexican flavor. This may result from the willingness to gain innovative consumers looking for a new, unusual experience when consuming food. Taking into account the number of savory and sweet flavors available under a particular brand, one can notice that dairy companies tend to develop products with savory flavors as a result of market demand.

The respondents were asked to choose the three most relevant. The new versions of flavors and the responses given by the respondents are presented in Figure 4.

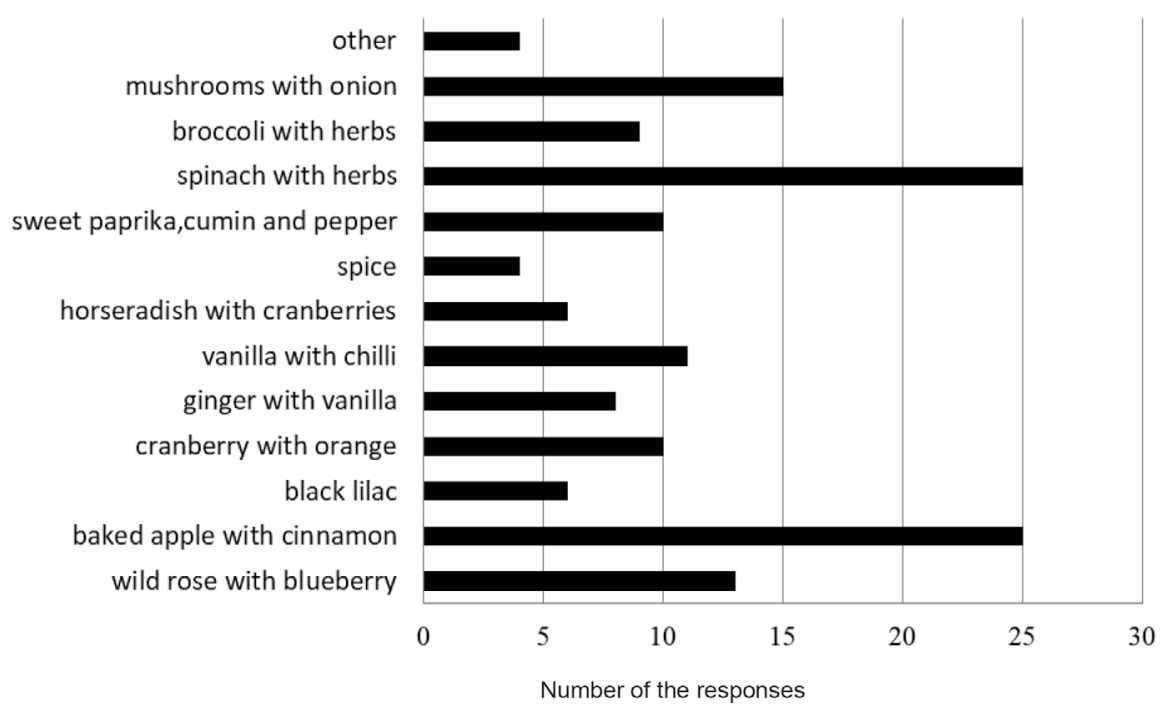

Fig. 4. Respondents' choices of new flavor versions suggested for tvarog cheese production 
Although the consumers declared their preference for sweet flavor variants, they often also declared a willingness to consume spicy versions. Among the new flavors of the product suggested, most people chose spinach with herbs and baked apple with cinnamon (each of the flavors was mentioned as one of the most preferred 25 times). Fifteen respondents chose mushroom with onion, and 13 wild rose with blueberry.

\section{Physico-chemical evaluation of new products}

The tvarog used to manufacture the aerated cheeses had $4.28 \%$ fat, $21.87 \%$ protein and $71.09 \%$ water (Table 1). Tvarog spreads were produced by mixing semifat tvarog with $3 \%$ of milk (milk fat content $3.2 \%$ ) and $12 \%$ of flavor preparation. The composition of tvarog used to manufacture aerated cheeses (without additives) and the final product (with additives) is shown in Table 1.

Table 1. Mean composition of cheeses with and without additives, $\%$

\begin{tabular}{lcccc}
\hline Type of cheese & Protein & $\begin{array}{c}\text { Dry } \\
\text { weight }\end{array}$ & Fat & Water \\
\hline Without additives & 21.87 & 28.91 & 4.28 & 71.09 \\
With additives & 16.10 & 27.07 & 3.98 & 72.93 \\
\hline
\end{tabular}

The new products were characterized by a higher protein content than tvarog cheeses (different varieties) commonly available on the market, even after flavor preparation was added. Tomczyńska-Mleko et al. (2014) analyzed selected aerated cheeses available on the market and showed that the average protein content ranged from 6 to $9 \%$. The fat content of commercial aerated tvarog cheeses ranged from 3 to 25\% (Tomczyńska-Mleko et al., 2014). Homogenized tvarog cheeses studied by Kłobukowski and Cichon (2000) had a protein content between 14 to $17 \%$ depending on the method of production. These cheeses were also characterized by a dry matter content similar to the experimented cheeses; from more than $16 \%$ for homogenized cheese to more than $28 \%$ for homogenized and thermized cheese.

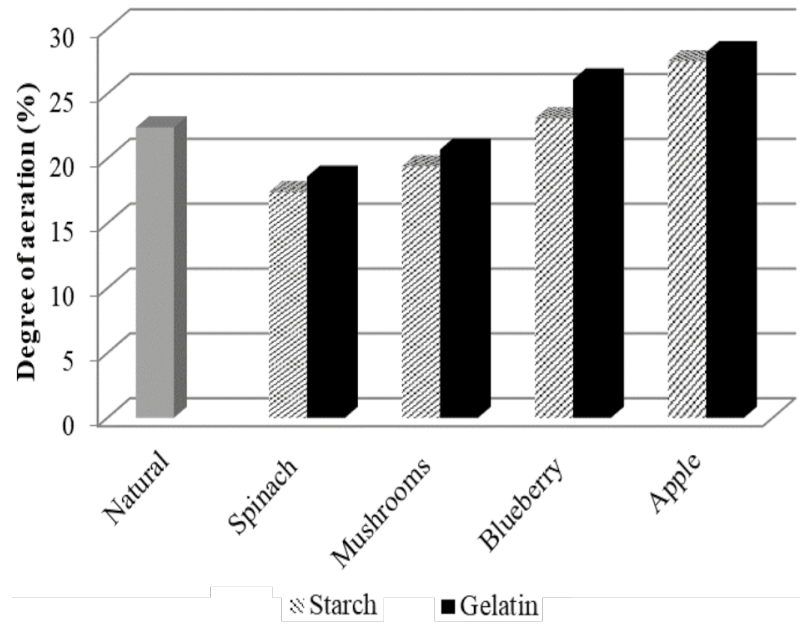

Fig. 5. The degree of aeration [\%] for tvarog cheeses of different flavours: natural, spinach with herbs (spinach), mushrooms with onion (mushrooms), blueberry with wild rose and black lilac (blueberry), baked apple with cinnamon (apple). Each version, except for the natural variant, was made either with starch or gelatine used to stabilize flavor preparation

The tvarog spread with baked apple with cinnamon flavor had the highest degree of aeration (\%N; Fig. 5). However, the lowest degree of aeration was shown by the products with spinach and herbs. In general, sweet tvarog spreads were characterized by a higher degree of aeration than cheeses with a savory flavor. In fact, the savory variants had a semi-liquid consistency after aeration. This could result from the addition of salt $(6 \%)$ to the flavor preparation. Each flavor version was produced in two variants, which differed in terms of the stabilizing agent: gelatine and starch. Generally, products stabilized by gelatine showed a higher degree of aeration than those with starch. Aeration depends to a large extent on the apparatus used for aeration, as well as on the production conditions. The degree of aeration of selected cheeses studied by Tomczyńska-Mleko et al. (2014) ranged from 15 to even more than $40 \%$.

The results of the TPA are shown in Table 2. The savory cheeses showed lower hardness than sweet cheeses $(P<0.05)$. For savory cheeses there were slight but not significant $(P>0.05)$ differences in hardness between the samples with different stabilizers used in the preparation of flavor additives. However, there were significant $(P<0.05)$ differences for 
Treszczynska, B., Siwek, A., Kowalik, J., Lobacz, A., Zulewska, J. (2018). Influence of flavors and stabilizers used on the preferences and properties of aerated tvarog curd cheese. Acta Sci. Pol. Technol. Aliment., 17(4), 335-346. http://dx.doi.org/10.17306/ J.AFS.2018.0591

Table 2. The results of texture profile analysis for the products manufactured

\begin{tabular}{|c|c|c|c|c|c|c|c|c|c|}
\hline & \multirow{3}{*}{ Natural } & \multicolumn{2}{|c|}{ Spinach with herbs } & \multicolumn{2}{|c|}{$\begin{array}{l}\text { Mushrooms } \\
\text { with onion }\end{array}$} & \multicolumn{2}{|c|}{$\begin{array}{c}\text { Baked apple } \\
\text { with cinnamon }\end{array}$} & \multicolumn{2}{|c|}{$\begin{array}{l}\text { Blueberry with wild } \\
\text { rose and black lilac }\end{array}$} \\
\hline & & \multicolumn{8}{|c|}{ stabilizer used to prepare the flavour preparation } \\
\hline & & starch & gelatine & starch & gelatine & starch & gelatine & starch & gelatine \\
\hline Hardness, $\mathrm{N}$ & $\begin{array}{l}20.96^{\mathrm{a}} \\
\pm 1.73\end{array}$ & $\begin{array}{r}2.53^{\mathrm{d}} \\
\pm 0.62\end{array}$ & $\begin{aligned} & 2.77^{\mathrm{d}} \\
\pm & 0.12\end{aligned}$ & $\begin{array}{c}2.15^{\mathrm{d}} \\
\pm 0.10\end{array}$ & $\begin{array}{c}2.27^{\mathrm{d}} \\
\pm 0.10\end{array}$ & $\begin{array}{r}9.09^{\mathrm{b}} \\
\pm 0.33\end{array}$ & $\begin{aligned} & 3.80^{c} \\
\pm & 0.12\end{aligned}$ & $\begin{array}{r}9.80^{\mathrm{b}} \\
\pm 0.12\end{array}$ & $\begin{array}{r}3.85^{\mathrm{c}} \\
\pm 0.06\end{array}$ \\
\hline Fracturability, $\mathrm{N}$ & $\begin{array}{c} \\
0.00^{\mathrm{b}} \\
\pm 0.00\end{array}$ & $\begin{array}{r}0.08^{\mathrm{a}} \\
\pm 0.01\end{array}$ & $\begin{array}{r} \\
0.00^{\mathrm{b}} \\
\pm 0.00\end{array}$ & $\begin{array}{c}0.09^{\mathrm{a}} \\
\pm 0.01\end{array}$ & $\begin{array}{c}0.00^{\mathrm{b}} \\
\pm 0.00\end{array}$ & $\begin{array}{r} \\
0.00^{\mathrm{b}} \\
\pm 0.00\end{array}$ & $\begin{array}{c}0.07^{\mathrm{a}} \\
\pm 0.01\end{array}$ & $\begin{array}{r}0.09^{\mathrm{a}} \\
\pm 0.01\end{array}$ & $\begin{array}{r}0.00^{\mathrm{b}} \\
\pm 0.00\end{array}$ \\
\hline Adhesiveness, $\mathrm{N}$ & $\begin{array}{l}-1.67^{\mathrm{a}} \\
\pm 0.31\end{array}$ & $\begin{array}{l}-2.50^{\mathrm{b}} \\
\pm 0.42\end{array}$ & $\begin{array}{l}-3.01^{\mathrm{b}} \\
\pm 0.16\end{array}$ & $\begin{array}{l}-1.60^{\mathrm{a}} \\
\pm 0.06\end{array}$ & $\begin{array}{l}-2.36^{\mathrm{b}} \\
\pm 0.12\end{array}$ & $\begin{array}{c}-11.48^{\mathrm{e}} \\
\pm 0.72\end{array}$ & $\begin{array}{l}-1.91^{\mathrm{a}} \\
\pm 0.06\end{array}$ & $\begin{array}{l}-4.41^{\mathrm{c}} \\
\pm 0.20\end{array}$ & $\begin{array}{l}-5.48^{\mathrm{d}} \\
\pm 0.23\end{array}$ \\
\hline Springiness & $\begin{aligned} & 1.00^{\mathrm{a}} \\
\pm & 0.07\end{aligned}$ & $\begin{array}{c}0.99^{\mathrm{a}} \\
\pm 0.08\end{array}$ & $\begin{array}{c}0.99^{\mathrm{a}} \\
\pm 0.08\end{array}$ & $\begin{array}{c}0.99^{\mathrm{a}} \\
\pm 0.04\end{array}$ & $\begin{array}{c}0.99^{\mathrm{a}} \\
\pm 0.06\end{array}$ & $\begin{array}{c}0.99^{\mathrm{a}} \\
\pm 0.07\end{array}$ & $\begin{array}{c}1.00^{\mathrm{a}} \\
\pm 0.01\end{array}$ & $\begin{array}{r}1.00^{\mathrm{a}} \\
\pm 0.05\end{array}$ & $\begin{array}{r}0.99^{\mathrm{a}} \\
\pm 0.05\end{array}$ \\
\hline Cohesiveness & $\begin{aligned} & 0.77^{\mathrm{d}} \\
\pm & 0.04\end{aligned}$ & $\begin{array}{c}0.63^{\mathrm{d}} \\
\pm 0.04\end{array}$ & $\begin{array}{c} \\
0.81^{\mathrm{c}} \\
\pm 0.04\end{array}$ & $\begin{aligned} & 0.91^{\mathrm{b}} \\
\pm & 0.02\end{aligned}$ & $\begin{array}{c}0.82^{\mathrm{c}} \\
\pm 0.02\end{array}$ & $\begin{aligned} & 1.04^{\mathrm{a}} \\
\pm & 0.08\end{aligned}$ & $\begin{array}{c}0.72^{\mathrm{d}} \\
\pm 0.01\end{array}$ & $\begin{array}{r}0.68^{\mathrm{d}} \\
\pm 0.03\end{array}$ & $\begin{array}{r}0.75^{\mathrm{d}} \\
\pm 0.02\end{array}$ \\
\hline Gumminess & $\begin{array}{l}16.17^{\mathrm{a}} \\
\pm 1.16\end{array}$ & $\begin{array}{r}1.59^{\mathrm{e}} \\
\pm 0.09\end{array}$ & $\begin{array}{r}2.24^{\mathrm{e}} \\
\pm 0.14\end{array}$ & $\begin{array}{c}1.96^{\mathrm{e}} \\
\pm 0.08\end{array}$ & $\begin{aligned} & 1.85^{\mathrm{e}} \\
\pm & 0.08\end{aligned}$ & $\begin{array}{r}9.45^{\mathrm{b}} \\
\pm 0.23\end{array}$ & $\begin{array}{c}2.74^{\mathrm{d}} \\
\pm 0.11\end{array}$ & $\begin{array}{r}6.68^{\mathrm{c}} \\
\pm 0.03\end{array}$ & $\begin{array}{r}2.90^{\mathrm{d}} \\
\pm 0.07\end{array}$ \\
\hline Chewiness & $\begin{array}{l}16.17^{\mathrm{a}} \\
\pm 1.34\end{array}$ & $\begin{array}{r}1.59^{\mathrm{e}} \\
\pm 0.07\end{array}$ & $\begin{aligned} & 2.24^{\mathrm{e}} \\
\pm & 0.16\end{aligned}$ & $\begin{array}{c}1.96^{\mathrm{e}} \\
\pm 0.12\end{array}$ & $\begin{array}{c}1.85^{\mathrm{e}} \\
\pm 0.06\end{array}$ & 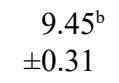 & $\begin{array}{c}2.74^{\mathrm{d}} \\
\pm 0.13\end{array}$ & $\begin{array}{r}6.68^{\mathrm{c}} \\
\pm 0.04\end{array}$ & $\begin{array}{r}2.90^{\mathrm{d}} \\
\pm 0.08\end{array}$ \\
\hline Resilience & $\begin{aligned} & 0.16^{\mathrm{a}} \\
\pm & 0.03\end{aligned}$ & $\begin{array}{r}0.08^{\mathrm{b}} \\
\pm 0.01\end{array}$ & $\begin{aligned} & 0.12^{\mathrm{ab}} \\
\pm & 0.03\end{aligned}$ & $\begin{aligned} & 0.11^{\mathrm{ab}} \\
\pm & 0.03\end{aligned}$ & $\begin{aligned} & 0.11^{\mathrm{ab}} \\
\pm & 0.02\end{aligned}$ & $\begin{aligned} & 0.10^{\mathrm{b}} \\
\pm & 0.02\end{aligned}$ & $\begin{aligned} & 0.15^{\mathrm{a}} \\
\pm & 0.02\end{aligned}$ & $\begin{array}{r}0.13^{\mathrm{a}} \\
\pm 0.01\end{array}$ & $\begin{array}{r}0.10^{\mathrm{b}} \\
\pm 0.01\end{array}$ \\
\hline
\end{tabular}

${ }^{\mathrm{a}-\mathrm{e}}$ Means in the same row not sharing a common superscript are different $(P<0.05)$.

sweet cheeses (blueberry with wild rose and black lilac, baked apple with cinnamon) with various stabilizers (starch or gelatine). The hardness for sweet cheeses with starch was almost 3 times higher than the hardness for the same flavor with gelatine. The hardness of natural cheese was significantly higher than for the products with flavor additives (20.96 N; Table 2), which was expected, since the control sample was milled tvarog aerated with nitrogen without any milk or flavors added.

Another of the parameters of new products that was studied was adhesiveness, which correlates to the work needed to overbear the forces between surface of the sample and surface of other objects. Cheese with baked apple and cinnamon flavor was characterized by very small adhesiveness (-11.48), while mushroom-flavored cheese had an adhesiveness of -1.60 ; both cheeses were stabilized by starch. In general, savory cheeses stabilized by starch had higher $(P<0.05)$ adhesiveness than the cheeses stabilized by gelatine. However, such dependencies were not noted for sweet cheeses. Cheeses studied by Tomczyńska-Mleko et al. (2014) had an adhesiveness ranging from -3.21 to -5.02 . Sweet variants of cheeses showed similar values of adhesiveness, although savory cheeses were characterized by greater adhesiveness. It must be noted that the TPA technique is not always the optimal method for quantifying adhesiveness. Adhesion is measured as the negative work between the two cycles. However, in many instances the product stuck to the probe and did not actually separate when the highest point between the two cycles was just back to the original product height. It is not surprising that the TPA method suggests that those products are more adhesive. Thus, reviewers should look skeptically at publications in which harder products appear to have higher adhesiveness (http://texturetechnologies. com/resources/texture-profile-analysis, 2018.02.23).

There were no differences $(P>0.05)$ in springiness for all the samples (Table 2). Springiness is calculated as the difference between the height of the sample before and after the first compression cycle (Bourne, 1978). 
The gumminess and chewiness values obtained for the same sample were identical, since the gumminess is calculated as hardness $\mathrm{x}$ cohesiveness, while chewiness is calculated as gumminess $\times$ springiness; the springiness for all cheeses was in the range $0.99-1.00$ (Table 2). The natural variant was characterized by significantly $(P<0.05)$ higher gumminess and chewiness in comparison with other variants, as a result of no milk or flavours being added. There were no differences $(P>0.05)$ between different stabilizers used among the same savory variant. However, the sweet variants with starch showed higher $(P<0.05)$ gumminess and chewiness than the variants with gelatine (9.45 vs 2.74 and 6.68 vs 2.90 for baked apple with cinnamon and blueberry with wild rose and black lilac, respectively; Table 2).

The resilience of the products studied was rather low; with a maximum value 0.16 for natural cheese.

\section{Evaluation of new products by consumers}

Consumers' assessments of the products being tested varied and were biased by their own preferences. The average scores given by consumers $(n=35)$ for each product (only variants with starch used as a stabilizer were tested by consumers) are shown in Table 3 . In general, the sweet variants were evaluated higher than the savory variants ( 4.0 and 4.2 for baked apple with cinnamon and blueberry with wild rose and black lilac variants versus 3.1 for both mushrooms with onion and spinach with herbs). The texture of sweet variants was significantly $(P<0.05)$ higher in comparison with savory variants. The sweet variants of tvarog cheeses showed higher values of the texture parameters (hardness, gumminess and chewiness) tested instrumentally than savory variants. This indicates that consumers prefer a more solid and firm consistency for this kind of the product.

Most consumers had no problem identifying the flavors used in the case of tvarog cheeses with baked apple and cinnamon flavor and mushrooms and onion, respectively: 22 and 33 respondents recognized the flavor properly. For the blueberry with wild rose and black lilac tvarog cheese, 17 people recognized the taste of berries, although no other additives (i.e. wild rose and black lilac) were identified by the evaluators. The might be the result of the low percentage content of these flavors, dominant role of berry flavor or unfamiliarity of the respondents with these flavors.

Table 3. Average scores for each product evaluated by consumers on a 5-point scale

\begin{tabular}{lcccc}
\hline \multicolumn{1}{c}{ Feature } & $\begin{array}{c}\text { Baked apple } \\
\text { with cinnamon }\end{array}$ & $\begin{array}{c}\text { Blueberry with wild } \\
\text { rose and black lilac }\end{array}$ & $\begin{array}{c}\text { Mushrooms } \\
\text { with onion }\end{array}$ & $\begin{array}{c}\text { Spinach } \\
\text { with herbs }\end{array}$ \\
\hline Overall appearance & $4.1^{\mathrm{a}} \pm 0.35$ & $4.3^{\mathrm{a}} \pm 0.62$ & $3.7^{\mathrm{b}} \pm 0.67$ & $3.5^{\mathrm{b}} \pm 0.56$ \\
Color & $4.2^{\mathrm{ab}} \pm 0,47$ & $4.4^{\mathrm{a}} \pm 0,64$ & $3.9^{\mathrm{b}} \pm 0,57$ & $3.8^{\mathrm{b}} \pm 0,63$ \\
Texture & $4.4^{\mathrm{ab}} \pm 0,49$ & $4.5^{\mathrm{a}} \pm 0,64$ & $3.9^{\mathrm{c}} \pm 0,29$ & $4.0^{\mathrm{bc}} \pm 0.31$ \\
Aroma & $4.0^{\mathrm{a}} \pm 0,50$ & $4.0^{\mathrm{a}} \pm 0,34$ & $3.8^{\mathrm{a}} \pm 0.67$ & $3.9^{\mathrm{a}} \pm 0.44$ \\
Perception of the additives & $3.6^{\mathrm{b}} \pm 0.39$ & $3.8^{\mathrm{b}} \pm 0.43$ & $4.2^{\mathrm{a}} \pm 0.59$ & $3.9^{\mathrm{ab}} \pm 0.52$ \\
General sensation & $4.0^{\mathrm{a}} \pm 0.44$ & $4.2^{\mathrm{a}} \pm 0.63$ & $3.1^{\mathrm{b}} \pm 1.05$ & $3.1^{\mathrm{b}} \pm 0.47$ \\
Flavour recognition & 22 evaluators & 17 evaluators & 33 evaluators & 7 evaluators \\
\hline
\end{tabular}

Boundary values of the scale

Overall appearance: 1 - not attractive at all, 5 - very attractive.

Color: 1 - very ununiformed, atypical of additives used, non-uniform distribution of additives, 5 - very typical of additives used, uniform, additives perfectly visible and uniformly distributed.

Texture: 1 - ununiformed, compact, with whey leakage, 5 - uniformed, creamy, little springy, without whey leakage.

Aroma: 1 -imperceptible, strongly perceptible foreign odors, 5 - well perceptible, fresh, typical for the product and additives used. Perception of additives: 1 -additives imperceptible, difficult to identify, 5 - additives well perceptible, easy to identify.

General sensation: 1 - definitely negative, 5 - definitely positive.

${ }^{\mathrm{a}-\mathrm{c}}$ Means in the same row not sharing a common superscript are different $(P<0.05)$. 


\section{Sensory evaluation of new products by the expert panel}

The expert panel $(n=10)$ evaluated all new versions of aerated tvarog cheeses, stabilized both by starch and gelatine. The average grades for each product tested by the expert panel are shown in Table 4.

In general, the sweet variants were evaluated higher than the savory products for both stabilizers

Table 4. Average grades for each product tested by the expert panel on a 7-point scale. The overall sensory sensation was rated using a 7-point scale

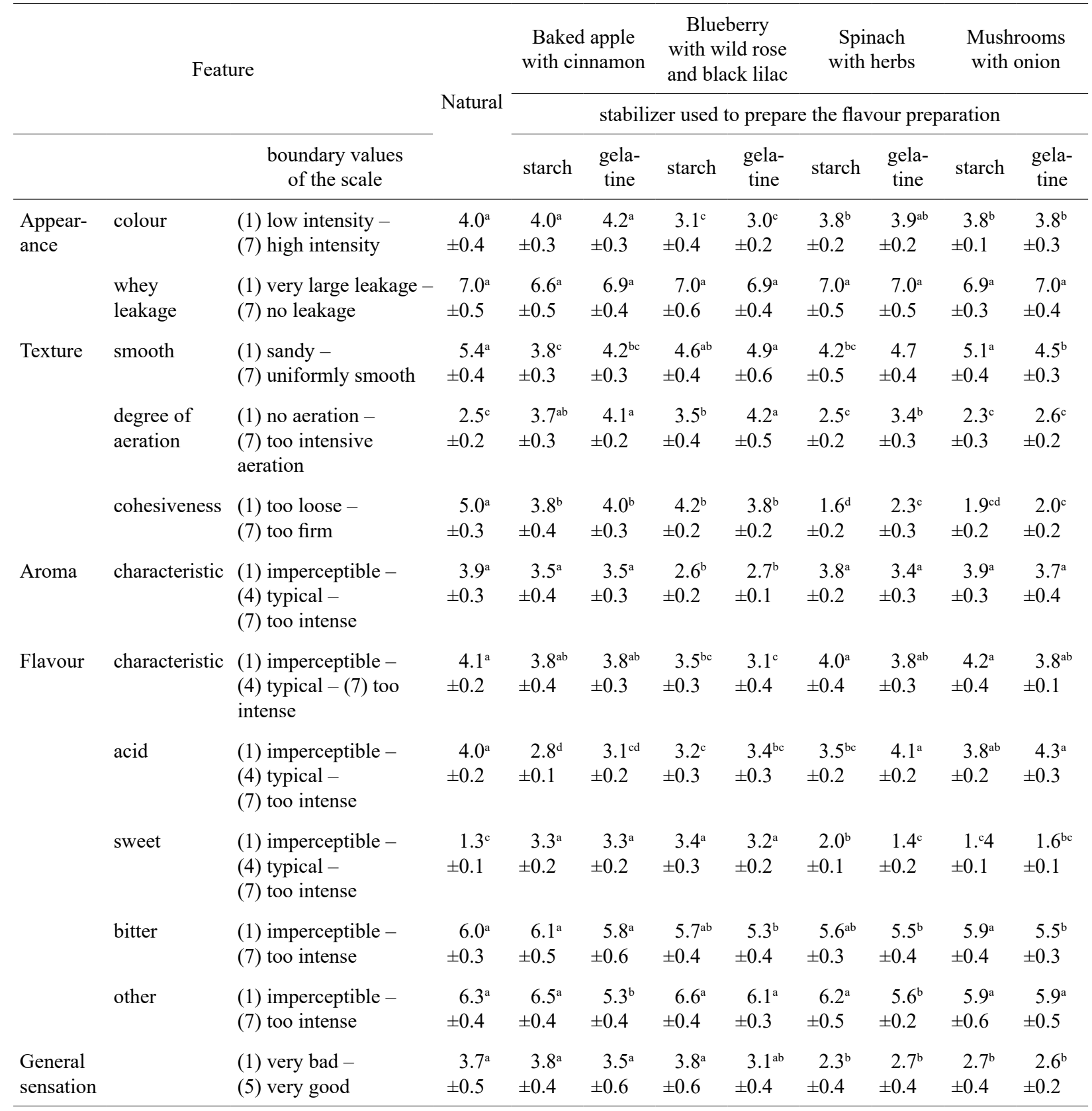

${ }^{a-c}$ Means in the same row not sharing a common superscript are different $(P<0.05)$. 
used. The colour of tvarog cheeses was described as the correct one. The colour of blueberry with wild rose and black lilac tvarog spread received the lowest scores (3.1 and 3.0 for the different stabilizers used, starch and gelatine, respectively) and was differed significantly $(P<0.05)$ compared with other products manufactured. This might be the result of the purple colour, which did not seem to be very appetizing. There was no visible leakage of whey in any kind of new product. In terms of texture, the natural cheese (control sample) was evaluated as soft but mealy. A slightly mealy texture was also noted for quark cheese flavored with mushrooms and onion stabilized by starch (Table 4).

The sweet variants stabilized by gelatine received the highest $(P<0.05)$ scores in terms of the degree of aeration (4.1 and 4.2 for baked apple with cinnamon and blueberry with wild rose and black lilac, respectively). The degree of aeration for other products was rated lower, with the lowest scores for natural tvarog cheese, spinach with herbs (stabilized by starch) and mushrooms with onion. However, the natural product exhibited a relatively low degree of aeration, but still remained cohesive. The texture of savory variants was described by the evaluators as not firm enough and too loose. The consistency of these products was rather dip-like, which correlates with the results of the TPA test, in which savory variants showed the lowest values for hardness (the correlation coefficient for TPA hardness and cohesiveness evaluated by experts was 0.77$)$. The addition of sodium chloride (6\%) to the flavor preparation for savory variants could impact the texture of the final products. Research carried out by Nastaj (2012) showed that the concentration of $\mathrm{NaCl}$ significantly affects the rheological properties of protein foams. He determined that a molar concentration of $\mathrm{NaCl}$ in the range of $240-280 \mathrm{mM}$ had a negative effect on the foams produced.

The new products were characterized by the appropriate aroma (Table 4). The lowest score of blueberry with wild rose and black lilac tvarog spread was the result of an inappropriate balance between the aromas used. In general, the aroma of this tvarog cheese was rather weak with the prevalence of blueberry, while other components (wild rose and black lilac) were practically undetectable. Moreover, in terms of flavor, blueberry with wild rose and black lilac tvarog cheese received the lowest scores. Based on the information provided by the manufacturer, the addition of black lilac juice constituted more than half of all fruit juices used.

The flavour of experimental tvarog spreads was appropriate (Table 4). The experts very often denoted the presence of dill-cucumber flavor in the spinach with herbs tvarog spread. According to the specification, only $5 \%$ of each component was used in flavor preparation. Bitter and other flavors were rather less palpable.

In general, the general sensation for natural and sweet variants was appropriate (Table 4). The savory variants received lower scores, which was the result of the dip-like consistency of these products. It is possible that a change in the recipe, i.e. the amount of milk added, could result in these products having a better texture. However, the texture of savory variants was not firm enough, probably as a result of salt being added to flavor preparations (Table 4).

The assortment of tvarog spreads is much greater than the traditional tvarogs, and undergoes continuous development. Currently, there are about 40 variants of flavored tvarog cheeses on the market, such as chives, radish, garlic, horseradish and herbs and sweet versions such as chocolate, vanilla or fruit. There are also premium products on the market with sophisticated flavors such as Borowikowy Las (porcini mushroom forest) and Orzechowa Aleja (nutty avenue). Additionally, flavors from different parts of the world can be found, such as Tuscan tomato, olive and spices, or spicy Mexican flavors. The products with an unusual sweet-spicy fusion, such as mustard and honey, are also available on the market. These products not only have sophisticated tastes, but also higher quality packaging, and a characteristic layout.

Today, consumers are seeking convenience food whose preparation is very quick and simple, or products for immediate consumption. On the other hand, they are more aware and expect healthy, nutritious products that have a positive impact on their body and body weight management (Bimbo et al., 2017).

\section{CONCLUSIONS}

The development of new flavor variants seems to be the fastest and the easiest way to launch a new product 
onto the market. However, a proper balance between different flavors used to manufacture the flavor preparation must be met. By introducing a new flavor variant, the producer increases the range of products offered, can reach other segments of the market and therefore increase the visibility of the brand. Another very important feature for products like aerated tvarog cheeses is texture. No stabilizers were used to stabilize the consistency of the new products, which affected consumers' acceptance. The texture of savory variants was not firm enough and too loose, which was probably the result of salt being added to flavor preparations. In general, tvarog is a good base for the production of both sweet and salty products due to its slightly sour taste and weak odor. When developing the composition of a new tvarog product with various flavors, the amount of milk added must be varied to obtain a consistency preferred by consumers. In current research, the sweet variants gained greater acceptance among consumers due to better texture.

\section{ACKNOWLEDGEMENTS}

The technical assistance of Waldemar Brandt, Roman Łaszek and Justyna Ziajka - the staff members of Department of Dairy Science and Quality Management, was greatly appreciated.

\section{REFERENCES}

Bimbo, F., Bonanno, A., Nocella, G., Viscecchia, R., Nardone, G., De Devitiis, B., Carlucci, D. (2017). Consumers' acceptance and preferences for nutrition-modified and functional dairy products: A systematic review. Appetite, 113, 141-154. https://doi.org/10.1016/j. appet.2017.02.031

Bobeł, Ł. (2008). Prawne warunki wprowadzania nowej żywności do obrotu [Legal conditions for placing new food on the market]. Przem. Spoż., 5, 14-17 [in Polish].

Bourne, M. C. (1978). Texture profile analysis. Food Technol., 32, 62-66.

Earle, E., Earle, R., Anderson, A. (2001). Food product development. Cambridge: Woodhead Publ.

Guinee, T. R., Pudia, R. D., Farkye, N. Y. (1993). Fresh acid curd cheese varieties. In: R. E. Fox (Ed.), Cheese chemistry, physics and microbiology. Vol. 2. Major cheese groups (pp. 363-419). London: Chapman \& Hall.
Kłobukowski, J., Cichon, R. (2000). Wartość odżywcza wybranych produktów mleczarskich. Cz. II. Wartość odżywcza serków twarogowych homogenizowanych i innych serów twarogowych niedojrzewających [Nutritional value of selected dairy products. Part II. Nutritional value of homogenized cottage cheese and other cottage cheese]. Przem. Spoż., 3, 40-41, 56 [in Polish].

Kroger, M. (1980). The manufacture of Quarg cheese. Cultur. Dairy Prod. J., 15(8), 11-14.

MacFie, H. (2007). Consumer-led food product development. Cambridge: Woodhead Publ.

Mann, E. (2000). Cheese product innovations. Dairy Ind. Int., 65(10), 17-18.

Moskowitz, H. R., Beckley, J. H., Resurreccion, A. V. A. (2006). Sensory and consumer research in food product design and development. Oxford: Blackwell Publ., Inst. Food Technol.

Nastaj, M. (2012). Wpływ chlorku sodu na właściwości reologiczne pian otrzymywanych $\mathrm{z}$ albuminy wysoko pienistej [Effect of sodium chloride on rheological properties of foams obtained from powdered high whip albumin]. Żywn. Nauka Technol. Jakość, 5, 113-123 [in Polish].

Rouyer, B. (1997). The Czech Republic: good prospects for foreign cheeses. Rev. Lait. Franc., 570, 28-29.

Rymaszewski, J., Smietana, Z. (1997). Sery dojrzewające i sery twarogowe [Ripening cheeses and tvarog cheeses]. In: S. Ziajka (Ed.), Mleczarstwo - zagadnienia wybrane (Vol. 1, pp. 188-209). Olsztyn: Wyd. ART [in Polish].

Rynek mleka. Stan i perspektywy [Milk market. Status and prospects], 52 (2017). Analizy rynkowe. Warszawa: IERiGŻ - PIB, Agen. Rynku Roln., Min. Roln. Rozw. Wsi [in Polish].

Schultz-Collins, D., Senge, B. (2004). Acid - and acid/ rennet-curd cheeses. Part A: quark, cream cheese and realted varietes. In: P. F. Fox, P. L. H. McSweeney (Eds.), Cheese: chemistry, physics and microbiology (3rd ed., vol. 2. Major cheese groups, pp. 301-318). Elsevier. https://doi.org/10.1016/S1874-558X(04)80049-6

Siemianowski, K., Szpendowski, J., Bohdziewicz, K., Kołakowski, P., Pawlikowska, K., Żylińska, J., Bardowski, J. (2013). Wpływ zawartości suchej masy w mleku na skład oraz cechy sensoryczne twarogu kwasowego [Effect of dry matter content in milk on composition and sensory properties of acidic tvarog]. Fol. Pomer. Univ. Technol. Stetin., Agric. Pisc. Zootech., 25, 113-124 [in Polish].

Siggelkow, M. A. (1984). Modern methods in quarg production for consumer sale. Dairy Ind. Int., 49(6), 17-21. 
Treszczynska, B., Siwek, A., Kowalik, J., Lobacz, A., Zulewska, J. (2018). Influence of flavors and stabilizers used on the preferences and properties of aerated tvarog curd cheese. Acta Sci. Pol. Technol. Aliment., 17(4), 335-346. http://dx.doi.org/10.17306/ J.AFS.2018.0591

Sojkin, B., Olejniczak, T. (2009). Źródła informacji o nowych produktach [Sources of information about new products]. Przem. Spoż., 7, 30-32 [in Polish].

Tomczyńska-Mleko, M., Baruk, A., Domańska, K., Wesołowska-Trojanowska, M., Mleko, S., Róg, S. (2014).
Właściwości reologiczne, teksturalne i sensoryczne napowietrzanych serków twarogowych [Rheological, textural and sensory properties of aerated cream cheese]. Ann. Univ. Mariae Curie-Skłod., 4, 84-93 [in Polish]. 